\title{
A brief report on ichthyofaunal diversity of Dewmai khola of Ilam district, Nepal
}

\author{
Jash H. Limbu', Geeta S. Acharya ${ }^{2}$ and Om H. Shrestha ${ }^{3}$ \\ ${ }^{1}$ Central Dept. of Zoology, Tribhuvan University, Kirtipur, Kathmandu, Nepal \\ ${ }^{2}$ Department of Zoology, Tri-Chandra Multiple Campus, Ghantaghar, Kathmandu, Nepal \\ ${ }^{3}$ Department of Zoology, Amrit Campus, Thamel, Kathmandu, Nepal \\ oshresth@gmail.com
}

\begin{abstract}
Fish diversity of Nepal has been poorly studied or understood relative to other fauna, so a lot of study is still required to have a better fish diversity profile. We investigated ichthyofaunal diversity on one of the unexplored rivers, Dewmai Khola which lies in mid-hill region of Ilam district in eastern Nepal. Fishes were collected from three sampling sites in day time by using a cast net with the help of local fisherman. The field visits were performed from December 2015 to September 2016. A total of 16 fish species belonging to 3 orders, 6 families and 11 genera have been recorded. The Cypriniformes was the dominant order represented by 3 families: 1) Cyprinidae with 7 species (Cirrhinus mrigala, Barilius barila, B. bendelisis, Bengala elanga, Danio aequipinnatus, Schizothoraichthys labiatus and Garra gotyla), 2) Cobitidae with 5 species (Schistura multifasciatus, S. horai, S. scaturigina, S. savona and S. rupecula) and 3) Psilorhynchidae with a single species Psilorhynchus pseudecheneis. The Perciformes was represented by two families with a single species in each: Belontidae (Colisa fasciatus) and Channidae (Channa stewartii). The Siluriformes was represented by a single family Sisoridae with a single species Glyptothorax pectinopterus.
\end{abstract}

Keywords: Dewmai Khola, diversity, fish, freshwater, Ilam

\section{INTRODUCTION}

Nepal is a less explored country regarding fish diversity (Shrestha, 2008). Moreover, fish diversity of Nepal has been poorly studied or understood relative to other fauna (Shrestha et al., 2009). A lot of research has yet to be carried out in many unexplored or virgin rivers across the country to understand better fish diversity. Being a landlocked country and not connected with the ocean, Nepal is a home for only freshwater fishes. It is one of the south Asian countries which is located between Palearctic and Oriental (Indomalayan) biogeographical realms (Udvardy, 1975), is rich in fish diversity (Shrestha, 2001; Rajbanshi, 2005; Sharma, 2008) where fishes are distributed in different water bodies such as rivers, streams, lakes, village ponds, reservoirs, swamps and paddy fields. Among water resources, rivers are the most important which covers about $49 \%$ of the total water body (Swar, 2002); about 6000 rivers and streams are scattered across the country (Shrestha, 1981).

Among the three major river drainages of Nepal: the Koshi in the eastern, the Gandaki in the central and the Karnali in the western region, the present study lies in Koshi drainage 
of eastern Nepal. The moderate study on fisheries resources has been done in the rivers of Koshi drainage. Some of the important studies in this drainage include: Bhagat (1985) studied fish and fishery resources of Morang district (diss.); Sapkota (1992) studied fishery ecology of the swamp lands of the Koshi River (unpubl.); Shrestha et al. (2009) studied fish diversity of Tamor and its major tributaries of eastern Himalayan region; Shah (2016) studied the freshwater fish diversity of Koshi Barrage etc.

The study of fish diversity is crucial to discover new species which will, in turn, contribute to add the number of species in diversity profile of the country. This is the first study which aims to investigate the fish diversity of one of the unexplored rivers, Dewmai Khola of Ilam district, to reduce the gap of knowledge and hence expand the fish diversity profile of Nepal.

\section{MATERIALS AND METHODS}

\section{Study area}

The Dewmai Khola, present study area, is one of the main rivers of llam district. This district has four main rivers: Dewmai Khola, Puwamai Khola, Jogmai Khola and Mulmai Khola. They are collectively known as Charkhol which means four khola/rivers. The Dewmai Khola lies in mid-hill region of llam district, far west from Ilam-bazzar, in eastern Nepal. It is perennial and torrential river which originates from Rake Bhanjyang and flows through the border of Panchthar and Ilam districts which finally merges with Mai Khola and flows onwards as Mai Khola that enters the Jhapa district. The water of Dewmai Khola is crystal clear except the rainy season. Due to steep gradient at upstream, the water velocity is higher than plain area at downstream. Mostly big boulders and rocks were the dominant river bed at upstream whereas cobble, pebble, gravel and sand were the dominant riverbed at downstream.

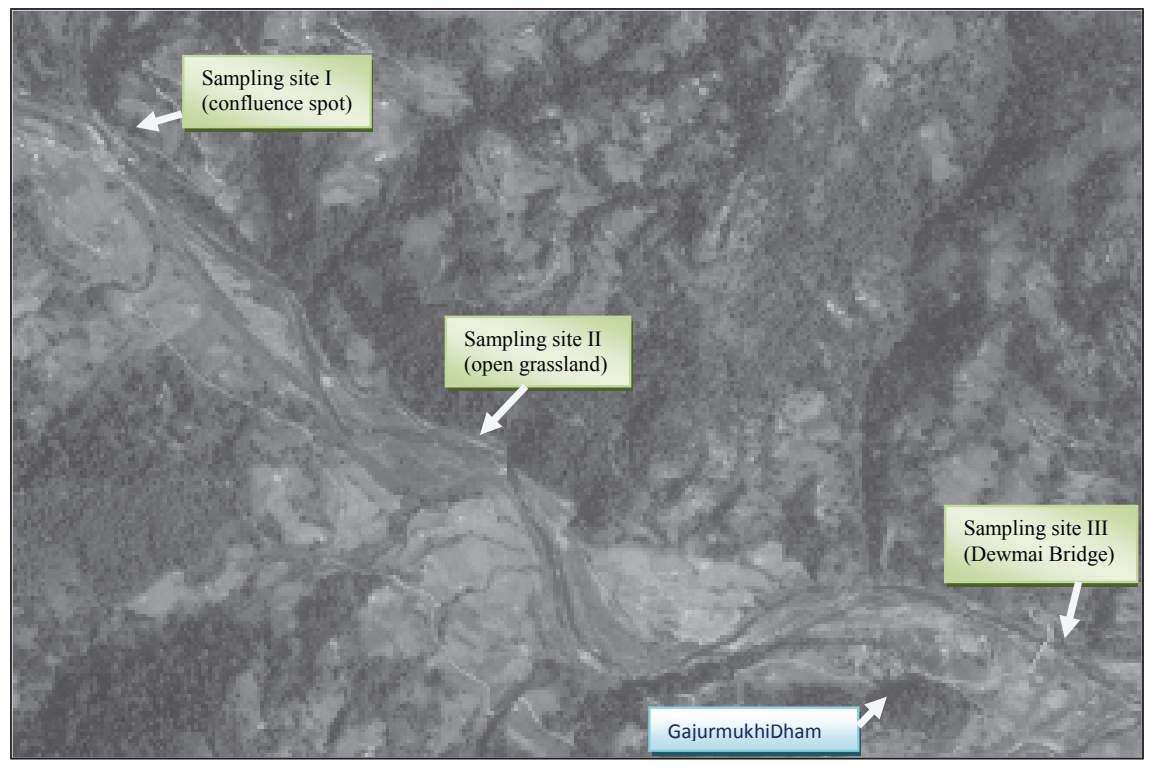

FIG. 1. The study area showing three sampling sites in Dewmai Khola, Ilam. 


\section{Sampling sites}

Altogether three sampling sites (fig. 1) I, II and III were designated along the sampling stretch of the Dewmai Khola. The first sampling site was selected at the confluence spot of two rivers; here another river called Fakfuk joins the Dewmai Khola. The sampling site II was selected near an open grassland area where local people graze their cattle and the third sampling site was chosen near Gajurmukhi brigde. The Gajurmukhi dham nearby the bridge is famous religious spot in Gajurmukhi municipality.

\section{Fish sampling}

Fishes were collected from designated sampling sites once every three months for a whole year. The first field visit was made on December 2015. The second, third and fourth field visits were performed in March, June and September of 2016 respectively. Each site was sampled about thirty minutes with the help of local fisherman by using cast net only. The collected fishes were photographed in fresh on the spot whenever possible, and some specimens were photographed in the Tri-Chandra Multiple Campus (TCMC) lab. The collected fishes were preserved in $10 \%$ formalin solution in plastic jars for further study in the TCMC lab. The collected fishes were identified using Shrestha (1981, 1994), Shrestha (2008) and Jayaram (2010). The specimens were deposited at TCMC lab as voucher specimens.

\section{RESULTS AND DISCUSSION}

A total of sixteen fish species belonging to 3 orders, 6 families and 11 genera (table 1.) have been recorded in this study. Among the three orders, Cypriniformes, Siluriformes and

TABLE 1. Total number of fish species, orders, families and subfamilies found in Dewmai Khola, Ilam district (2015/2016).

\section{ORDER CYPRINIFORMES}

\section{Family Cyprinidae}

Subfamily-Cyprininae

Cirrhinus mrigala (Hamilton 1822)

Subfamily Danioninae

Barilius barila (Hamilton 1822)

Barilius bendelisis (Hamilton 1807)

Danio aequipinnatus (McClelland 1839)

Subfamily Schizothoracinae

Schizothoraichthys labiatus (McClelland 1839)

Subfamily Garrinae

Garra gotyla (Gray 1830)

\section{Family Cobitidae}

Subfamily Nemacheilinae 
Limbu et al. : A brief report on ichthyofaunal diversity of Dewmai khola.....

Schistura multifasciata (Day 1878)

S. horai (Menon 1952)

S. scaturigina McClelland 1839

S. savona (Hamilton 1822)

S. rupecula McClelland 1838

Family Psilorhynchidae

Psilorhynchus pseudecheneis Menon and Datta 1964

ORDER SILURIFORMES

Familiy Sisoridae

Glyptothorax pectinopterus (McClelland 1842)

ORDER PERCIFORMES

\section{Family Belontidae}

Colisa fasciatus (Bloch \& Schneider 1801)

\section{Family Channidae}

Channa stewartii (Playfair 1867)

Perciformes, the Cypriniformes was the dominant order which represented $82 \%$ of whole collection and comprised of three families, i.e., Cyprinidae, Cobitidae and Pshilorhynchidae. Families Cyprinidae and Cobitidae are represented by 7 and 5 species respectively, while a single species, Psilorhynchus pseudecheneis is represented by Cobitidae (fig 2). Among them, Garra and Barilius species were fairly common among all sampling sites. The Perciformes represented $11 \%$ of total collection comprising two families with a single species in each, Belontidae (Colisa fasciatus) and Channidae (Channa stewartii). Channa stewartii is caught by hands in backwaters of second sampling site. The Siluriformes represented $7 \%$ of total collection including only one family Sisoridae with a single species Glyptothorax pectinopterus.

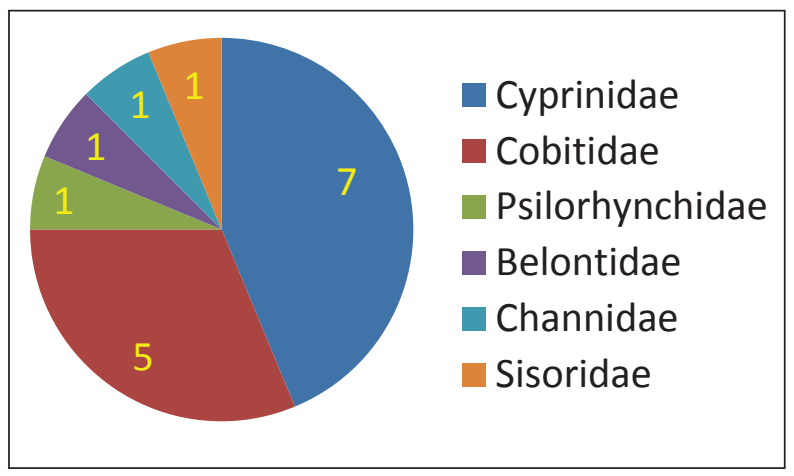

FIG. 2. Showing six fish families recorded in Dewmai Khola, Ilam district (2015/2016). 
In most of the places water from local farmlands drain out into the river (Dewmai Khola); therefore, the chemicals or pesticides used in farmlands may have negative effects on fish diversity. As mentioned earlier, the second site is near an open grassland area where people graze their cattle might have negative impacts for aquatic life, including fish. For example, excreta of cattle and consequences of soil pollution due to grazing near the river bank may have adverse effects. To address this, a thorough research is necessary in future.

According to local fishermen different illegal fishing practices such as electro-fishing, use of poison, etc. are frequent in this river, and are responsible for declining fish species such as Labeo, Tor, Anguilla spp., etc. We could not find those species in our collection too. They opined that the population of above mentioned species might have been severely depleted. However, being a short survey with limited field visits, this study may not enough to draw conclusion regarding that, but we could not simply ignore local knowledge as well. The combination of local knowledge and scientific research can provide better insight for biodiversity, such as fish diversity.

Being a less explored country (Nepal) regarding fish diversity, the study like this plays an important role for updating fish diversity status. If we talk about the country's overall fish diversity, 51 new fish species have been added to ichthyofauna of Nepal within the period of about two and half decade (Shrestha, 1995; Shrestha, 2019). The need of not only the extensive fish diversity study in many virgin rivers is strongly realized but also the appreciation of deposition of voucher specimens should greatly be emphasized so that diversity status/ claim of fishes is verifiable and more reliable (Shrestha and Edds, 2012).

\section{ACKNOWLEDGMENTS}

Our sincere thanks go to local fisherman, Mr. Chhabi Lal Limbu and his family, for fish collection, lodging and food during field visits. We also express our heartfelt thanks to all who helped us directly or indirectly for this research, and the staffs of Department of Zoology, TriChandra Multiple Campus, Kathmandu.

\section{REFERENCES}

BHAGAT, R P (1985) Study on the fish and fishery resources of Morang District, Koshi Zone. M.Sc dissertation, Zoology, Tribhuvan University, Kathmandu, Nepal.

JAYARAM, K. C. (2010) The freshwater fishes of the Indian region. Narendra Publishing House, Delhi, India; $614 \mathrm{pp}$.

RAJBANSHI, K G (2005) Review on current taxonomic status and diversity of fishes in Nepal. Academy of Science and Technology. Occasional paper, 10: 41.

SAPKOTA, K (1992) A study of the fishery ecology of the swamp lands of the Koshi River. M.Sc. dissertation, Zoology, Tribhuvan University, Kathmandu, Nepal.

SHAH, P (2016) Study of freshwater fish diversity of Koshi River of Nepal. International Journal of Fauna and Biological Studies 3: 78-81.

SHARMA, C M (2008) Freshwater fishes, fisheries, and habitat prospects of Nepal. Aquatic Ecosystem Health and Management 11: 289-297. 
Limbu et al. : A brief report on ichthyofaunal diversity of Dewmai khola.

SAUND, T B; SHRESTHA, J (2007) Fish and benthic fauna in Kulekhani reservoir. Nepal Journal of Science and Technology 8: 63-68.

SHRESTHA, J (1981). Fishes of Nepal. Curriculum Development Centre, Tribhuvan University,

Kathmandu, Nepal; pp. 318 pp.

SHRESTHA, J (1994) Fishes, fishing implements and method of Nepal. Published by Smt. M.D. Gupta, Lalitpur Colony, Lashkar (Gwalior), India.

Shrestha, J (1995) Enumeration of the fishes of Nepal. Biodiversity Profiles Project Publication No. 10. Department of National Parks and Wildlife Conservation, Ministry of Forests and $\quad S \quad 0 \quad i \quad$ I Conservation. His Majesty's Government of Nepal, Kathmandu, Nepal; 64 pp.

SHRESTHA, J (2001) Taxonomic revision of fishes of Nepal. In JHA, P K; BARAL, S R; KARMACHARYA, S B; LEKHAK, H D; LACOUL, P; BANIYA, C B (eds) Biodiversity, agriculture and pollution in South Asia. ECOS, Kathmandu, Nepal; pp 171-180.

SHRESTHA, J; SINGH, D M; SAUND, T B (2009) Fish diversity of Tamor river and its major tributaries of eastern Himalayan region of Nepal. Nepal Journal of Science and Technology 10: 219-223.

SHRESTHA, O H; EDDS, E D (2012) Fishes of Nepal: mapping distributions based on voucher specimens. Emporia State Research State 48: 14-21.

SHRESTHA, T K (2008) Ichthyology of Nepal. A study of fishes of the Himalayan waters. Himalayan Ecosphere. Kathmandu, Nepal; 1-388 pp.

SHRESTHA, TK (2019) Ichthyology of Nepal. B. J. Shrestha Publisher, Kathmandu, Nepal; 509 pp.

SWAR, D B (2002) The status of cold water fishes and fisheries in Nepal and prospects of their utilization for poverty reduction. FAO. Fish, Tech, 143.

UDVARDY, M D F (1975) A classification of the biogeographical provinces of the world. IUCN

Occasional Paper no. 18. International Union for Conservation of Nature. Morges, Switzerland. 